\title{
GOD'S KINGDOM IN THE LAW'S REPUBLIC: RELIGIOUS FREEDOM IN SOUTH AFRICAN CONSTITUTIONAL JURISPRUDENCE ${ }^{1}$
}

Irma J Kroeze

BA Hons (BA) LLB LLM LLD

Department of Jurisprudence, UNISA

The wish to condemn and the desire to understand does not combine easily, and if we ignore the effect

of language on understanding we will no doubt tend to condemn only what we do not understand. ${ }^{2}$

\section{INTRODUCTION}

Freedom is central to most constitutions. In the constitutional context, freedom usually means both personal freedom and political freedom. Personal freedom can be described as the right to decide for oneself the terms of one's life, both individually and communally. It is what Frank Michelman calls self-rule: it "demands the people's determination for themselves of the norms that are to govern their social life". ${ }^{3}$ Political freedom, on the other hand, implies the protection against arbitrary government power. This is what Michelman calls law-rule. In most constitutional dispensations both these types of freedom are implicated and the South African constitution is no exception. ${ }^{4}$ But, it is ironic that in most constitutional democracies these two types of freedom are also frequently in conflict with one another. In fact, it is not far-fetched to suggest that they are conceptually contradictory.

1 My thanks to Paul du Plessis and Rena van den Bergh who read an earlier draft of this paper and made helpful comments. Any viewpoints and/or mistakes are my own.

2 Van der Walt AJ "Modernity, normality, and meaning: the struggle between progress and stability and the politics of interpretation" 2000 Stell LR 21-49, 226-243 243.

3 Michelman F "Law's republic" 1988 Yale LJ 1493-1537 1501.

4 Personal freedom is guaranteed by sections $9-16$ and political freedom is guaranteed by sections $17-20$ of the Constitution. But many sections guarantee both: see sections 31 and 32 . 
Religious freedom is one of the sites where this conflict is often played out. Religion is one of the factors that influence the value-choices made in the process of self-rule. Where these religious choices come into conflict with legislation, the question of priority becomes relevant. This paper deals with the ways in which the South African Constitutional Court has dealt with the question of religious freedom as an illustration of its basic underlying approach to the question of the conflict between self-rule and law-rule. For this purpose Michelman's analysis of the difference between the liberal pluralist and republican approaches will be used as basis. The purpose is not to provide a new theory of religious freedom or to prescribe new ways of dealing with this problem, but to give a critical perspective on current approaches.

The first part of this paper is a summary of Michelman's analysis and theory regarding the conflict that he regards as basic to American constitutionalism. The second part is a critical analysis of three constitutional court cases dealing with religious freedom. The third part attempts to use the Michelman analysis to provide a different perspective on these cases.

\section{LAW'S REPUBLIC}

American constitutional jurisprudence is based on two premises regarding political freedom. On the one hand it is stated that freedom requires selfgovernment and on the other hand that freedom requires government by laws and not by men. ${ }^{5}$ Self-government or self-rule demands that people determine for themselves what values will govern their social lives. Law-rule demands protection against arbitrary power by prescribing general rules that must be obeyed. ${ }^{6}$ In the case of self-rule a further distinction can be made between negative liberty (the absence of restraint) and positive liberty (that action be governed by reasons or laws one gives oneself). ${ }^{7}$ Positive liberty requires citizenship, negative liberty does not. 
It should be immediately apparent that self-rule and law-rule can be contradictory. Without a doubt some value-choices will be in conflict with legal rules that law-rule requires one to obey. The question then is whether self-rule or law-rule will have priority.

Michelman explains how the contradiction is handled in American constitutional jurisprudence with reference to the decision in Bowers $v$ Hardwick. $^{8} \quad$ In this case the American Supreme Court upheld the constitutionality of a Georgia statute that criminalizes sodomy, even if performed in private with a consenting adult. ${ }^{9}$ Michelman's problem with the decision is its "excessively detached and passive judicial stance toward constitutional law". ${ }^{10}$ This stance refers to a judicial attitude of deference to external authority. In order to enforce public values as law, the court needs to equate them with recent legislation or with the historical teaching of past authority. Michelman calls this judicial stance "authoritarian":

(I)t regards adjudicative actions as legitimate only insofar as dictated by the prior normative utterance, express or implied, or extra-judicial authority. ${ }^{11}$

This is the direct result of what Michelman calls the court's positivism and this positivism is the result of the fear for the counter-majoritarian difficulty. ${ }^{12}$ To avoid this difficulty, the court regards itself as an organ of law, not of politics. What is more, "(t)he Court is the servant, not the author, of a prescriptive text"13 - therefore it inquires into meaning, not reason or values.

But why should this be the case? The answer, according to Michelman, is a specific view of democracy. In this view, disputed questions of value are understood as a battle of preferences or the exertion of an arbitrary will. Law

$8 \quad$ Bowers $v$ Hardwick 478 US 186 (1986).

9 See, in this regard, the SA CC's different treatment of this question in National Coalition of Gay and Lesbian Equality and another $v$ Minister of Justice and others 19991 South Africa 6 (CC). The difference is probably due to differences in the two constitutional texts and not to a basic liberal attitude in the case of South Africa.

10 Michelman 1988 Yale LJ 1496.

11 Michelman 1988 Yale LJ 1496.

12 See Michelman 1998 California LR 471-472 where he states that the term "difficulty" might be "too gentle". It is rather a case of it being an impossibility. 
mediates this battle, but its legitimacy depends on not taking sides, which requires the application of extra-judicial authority. Democracy therefore answers this need for extra-judicial authority. ${ }^{14}$ Law cannot be part of the battle, its legitimacy must rest on some "higher" authority.

It seems clear that the question of the conflict between self-rule and law-rule deals with very fundamental issues. At its heart are the questions of the relationship between law and politics and of the nature of politics.

\subsection{The problem with liberal pluralism}

The attitude of the court in the Hardwick case can be regarded as typical of what Michelman calls pluralism ${ }^{15}$ or, elsewhere, liberal pluralism. ${ }^{16}$ As has already been stated, the pluralist rejection of the connection between law and politics is based on a specific view of democracy. This view is, in turn, based on a specific view of politics.

Pluralism, according to Michelman, is the view that it is impossible for people to communicate effectively and persuasively about values, because there are no common goals or ends. ${ }^{17}$ If common goals do exist, they are simply the aggregate of individual goals that happen to coincide. Pluralist politics is therefore a market-like medium for maximising individual preference. In such a scheme, common goods/ends are impossible.

Law, on the other hand, originates in the simultaneous acts of constituting and limiting the people as sovereign. For the law to serve the purpose of constituting a self-governing people, it must of course originate in politics. But if the law is also to effectively limit political will, it cannot remain grounded in politics. Law becomes "an autonomous force against politics, a force

14 Michelman 1988 Yale LJ 1499.

15 It is possible to substitute pluralist with liberalist, since the term pluralist has a quite different meaning in South African theory. But, since it is the term used by Michelman, it will be used here.

$16 \quad$ Michelman 1989 Florida LR 445.

17 Michelman 1988 Yale LJ 1507. See also Michelman 1989 Florida LR 445. 
elaborated through its own nonpolitical modes of reason and its own nonpolitical, judicial organ". ${ }^{18}$

But if politics does not provide the legitimation of law, what does? In the pluralist view, the legitimacy is derived from some objective idea of reason/nature/utility/etc. ${ }^{19}$ Once this objective basis is found, law can be severed from politics. ${ }^{20}$

(T)he only form of discursive validation available for a constitution is the metaphysical-not-political appeal to rationality or natural law: that is, the appeal to that constitution just being, as a demonstrable matter of objective reason, the right constitution for a country such as ours is fated to be, populated by folks such as we by nature are. ${ }^{21}$

It seems clear that the pluralist view is based on the individualist and objectivist paradigm of liberalism. Ironically the individualism in this approach did not lead to the expected outcome in the Hardwick case. That is because the severance of law and politics and the elevation of law above politics, makes the prioritisation of law-rule over self-rule inevitable.

\subsection{Michelman's alternative}

Michelman rejects the individualism of liberal pluralism. Republicans accept the notion of a common good that is more than the sum of individual interests. This is based on the "dialogic conception", namely that an individual is at least partly constituted by his/her social situation or context. ${ }^{22}$ However, this is not communitarianism. The concern is still with the welfare of individuals, but never as if they are somehow separate from their social context. ${ }^{23}$

Michelman also rejects what he calls classical republicanism. This type of republicanism, for Michelman, is the defence of repressive and discriminatory laws whose only justification lies in majority views on morality. This morality is

18 Michelman 1988 Yale LJ 1509.

19 Michelman 1989 Florida LR 446: "[F]or liberals, some rights are always grounded in a "higher law" of transpolitical reason or revelation."

20 Michelman 1988 Yale LJ 1511.

21 Michelman 1988 Yale LJ 1516.

22 Michelman 1989 Florida LR 444, 450. 
"Judeo-Christian" in nature and represents a commitment by the political community to this kind of morality based on its history. ${ }^{24}$ Michelman accepts that this kind of "strong" communitarianism can lead to a very harsh repression of minority views and choices.

Michelman therefore rejects the "strong" communitarianism of classical republicanism in favour of a different view of politics. This view is based on the idea of politics that includes those traditionally excluded in order to enhance or renovate political communities. As such it involves "a kind of normative tinkering" - a re-vision and re-cognition of normative histories. ${ }^{25}$

In republicanism the normative character of politics depends on the independence of mind and judgement, the authenticity of voice and, sometimes, on the plurality of views in debate. ${ }^{26}$ Thus, republicanism recognises both the dependence of politics on social and economic conditions and the dependence of these conditions on the legal order. This explains the republican attachment to rights, especially rights to speech and property. ${ }^{27}$ Rights are ultimately determinations of prevailing political will. ${ }^{28}$

Republicanism is also committed to jurisgenerative politics. The only problem is that jurisgenerative politics depends on the existence of normative consensus that seems to deny plurality. ${ }^{29}$

In reaction to pluralism, republicanism therefore rejects the market approach to politics and instead maintains that the political process can produce a

23 Michelman 1998 California LR 474.

24 Michelman 1988 Yale LJ 1495. See Mensch EV "The colonial origins of liberal property rights" 1982 Buffalo LR 635-735 on the early history of classical republicanism.

25 Michelman 1988 Yale LJ 1495.

26 Michelman 1988 Yale LJ 1504.

27 Michelman 1988 Yale LJ 1505. Republican thought thus demands some way of understanding how laws and rights can be both the free creations of citizens and, at the same time, the normative givens that constitute and underwrite a political process capable of creating constitutive law.

28 Michelman 1989 Florida LR 446.

29 Michelman 1988 Yale LJ 1506. This is a very narrow view of jurisgenerative politics. The view of Robert Cover, to my mind, seems to require dissensus for the creation of various versions of the law. See Cover R "Nomos and narrative" in Minow M, Ryan 
normative doctrine that commands respect as law. ${ }^{30}$ This political process is based on the idea of "an autonomous public interest independent of the sum of individual interests". ${ }^{31}$ Therefore justificatory arguments are not based on reason/nature, but on the way in which people in actual social conditions accept the law. ${ }^{32}$ This is the case because republicanism is based on a specific view of citizenship, namely citizenship as activity, or "the constant redetermination by the people for themselves of the terms on which they live together". ${ }^{33}$

As a result, the conflict between self-rule and law-rule is less problematic. In fact self-rule and law-rule become basically the same thing. Law is based on politics and politics is the constant re-determination of the terms under which we live. Law-rule is therefore based on dialogic self-rule.

This approach does, however, translate into a problem regarding constitutional interpretation: how to remain true to the historical text and, at the same time, give voice to those excluded by that very historical text. This is only possible if courts are allowed to change the interpretation in a progressive direction. The traditional view is to see courts as agents of the constitutional past. The court's role is then benedictory, never prophetic. ${ }^{34}$ According to this traditional view, the only alternative is "the nihilist menace". ${ }^{35}$ Michelman illustrates the two possible approaches of the court by contrasting the Hardwick decision with the Brown decision. ${ }^{36}$

(T)he Brown Court spoke in the accents of invention, not of convention; it spoke for the future, criticizing the past; it spoke for law, creating authority; it engaged in political argument. In Hardwick's case, the Court did the opposite. ${ }^{37}$

$\mathrm{M}$ and Sarat A (eds) Narrative, violence and the law (University of Michigan Press 1992) 95-172.

$30 \quad$ Michelman 1988 Yale LJ 1509.

$31 \quad$ Michelman 1989 Florida LR 445.

32 Michelman 1988 Yale LJ 1511.

33 Michelman 1988 Yale LJ 1518. This is what CLSers would simply call politics.

34 Michelman 1988 Yale LJ 1520.

35 See Singer JW "The player and the cards: nihilism and legal theory" 1984 Yale LJ 170.

36 Brown v Board of Education 347 US 483 (1954).

$37 \quad$ Michelman 1988 Yale LJ 1524. 
According to Michelman, plurality in a society always implies indeterminacy. This indeterminacy is the precondition for critique and dialogue. ${ }^{38}$ In the process of criticism and dialogue, the voices of "the other" are heard to take part in and/or disrupt the dialogue and this, Michelman argues, leads to political freedom through law. ${ }^{39}$ A court engaged in republican practice will therefore challenge the self-enclosing and self-satisfied tendency of people to accept their own moral completion, as this will deny the plurality on which transformation depends. ${ }^{40}$

The court's decision in Hardwick is therefore suspect in the republican sense. It denies homosexual participation in the public dialogue (a requirement for freedom) by reinforcing majoritarian ideas. It also denies freedom by privatising morality. ${ }^{41}$ As a result, personal moral choice becomes a matter for criminal law and as such, it undermines freedom. ${ }^{42}$ As Michelman states:

According to what I understand to be a republican ideal conception, politics is a field in which persons reciprocally exercise their capacities for changing and becoming by and through communicative relations. It is a dialogic process of persons overcoming, through confrontation with difference, the moral stasis and self-satisfaction of sameness. ${ }^{43}$

\section{THE CONSTITUTIONAL COURT'S APPROACH}

\subsection{Never on a Sunday}

38 This is what Michelman calls deliberative politics as the "argumentative interchange among persons who recognise each other as equal in authority and entitlement to respect". See Michelman 1989 Florida LR 447. Admittedly, this type of politics is not limited to republicanism.

39 Michelman 1988 Yale LJ 1528-1529. See also Michelman 1989 Florida LR 450, 451.

40 Michelman 1988 Yale LJ 1532

41 Michelman 1988 Yale LJ 1533.

42 Michelman 1988 Yale LJ 1536.

43 Michelman 1989 Florida LR 485. 
In the case of $S$ v Lawrence; $S$ v Negal; $S v$ Solberg ${ }^{44}$ the Constitutional Court had its first chance to deal with religious freedom. In the court a quo the appellants were convicted of various offences in terms of the Liquor Act. ${ }^{45}$ They did not deny the contraventions, but attacked the constitutionality of various sections of the Liquor Act. The allegation was that these sections were inconsistent with section 26 (right to economic activity) and section 14 (freedom of religion, belief and opinion) of the interim constitution. ${ }^{46}$ All three appellants were convicted as charged and noted an appeal to the Constitutional Court.

In the Constitutional Court the majority dismissed all three appeals. O'Regan $\mathrm{J}$, Goldstone $\mathrm{J}$ and Madala $\mathrm{J}$ dismissed the appeals of the first two appellants (based on freedom of economic activity), but upheld the third (based on freedom of religion). Sachs $\mathrm{J}$ delivered a separate judgement, but concurred with the majority decision. This discussion will only deal with that part of the judgement that deals with religious freedom and the emphasis will, for obvious reasons, be on the majority decision.

Regarding religious freedom the appellant argued that the purpose of prohibiting the selling of alcohol on so-called "closed days"47 was "to induce submission to a sectarian Christian conception of the proper observance of the Christian sabbath and Christian holidays or, perhaps, to compel the observance of the Christian sabbath and Christian holidays" [85]. The argument was therefore that the selection of these specific days showed that the legislation had a religious purpose and, as such, it constituted an

$44 \quad S \vee$ Lawrence; $S \vee$ Negal; $S$ v Solberg 19974 SA 1176 (CC). Numbers in square brackets in the text refer to the specific paragraphs in the judgement.

45 Liquor Act 27 of 1989 - hereinafter referred to as the Liquor Act. The offences were selling wine after the hours designated by the license, selling beer and cider while only allowed to sell wine and selling wine on a Sunday. This discussion will only deal with the last offence.

46 Constitution of the Republic of South Africa 200 of 1993.

47 Section 2 of the Liquor Act defines "closed day" as meaning Sunday, Good Friday and Christmas Day. 
infringement of section 14. In support of its argument, appellant relied on the decision in the Canadian case of $R v$ Big M Drug Mart. ${ }^{48}$

Chaskalson, writing for the majority, however distinguished that case from the present one on the basis that the Canadian Lord's Day Act had a "purely religious purpose and was designed to compel adherence to the Christian Sabbath" [90]. The Liquor Act, on the other hand, is "materially different in (its) scope and effect", and does not compel sabbatical adherence [90]. The court then points out that alcohol can be sold in closed days in a wide variety of places [90], but not under a grocer's wine licence.

The court states that it is aware that certain beliefs may be elevated through subtle means and that this can have the effect that "adherents of other religions may be made to feel that the state accords less value to their beliefs than it does to Christianity" [93]. But for various reasons the court does not feel that this is the case here. In the first place it is only the selling of alcohol that is prohibited [94]. In the second place, in South Africa "sundays have acquired a secular as well as a religious character" [95]. In fact, most people regard Sundays as a rest day, simply because it is convenient to do so.

Because of these two reasons, and because no evidence was placed before the court to indicate how the section interfered with religious freedom, the court found that "it is difficult to discern any coercion or constraint ... (because) ... the section does not compel licencees or any other person, directly or indirectly, to observe the Christian sabbath" [97].

Legislation would contravene section 14 if the endorsement of a specific religion "has the effect of coercing people to observe the practices of a particular religion, or of placing constraints on them in relation to the observance of their own religion" [104]. In this case, however, the connection between Christianity and the restriction on Sunday trading is "too tenuous" to establish an infringement on religious freedom [105]. Canadian Lord's Day Act which compelled the observance of Sunday as "the Lord's day." 
Sachs $\mathrm{J}$ agreed with the majority view on the tenuous connection between the purpose of the Liquor Act and Christianity, ${ }^{49}$ but argued that the choice of Sundays has a negative symbolic effect:

What comes through as an innocuous part of daily living to one person who happens to inhabit a particular intellectual and spiritual universe might be communicated as oppressive and exclusionary to another who lives in a different realm of belief. What may be so trifling in the eyes of members of the majority or dominant section of the population as to be invisible may assume quite large proportions and be eminently real, hurtful and oppressive to those upon whom it impacts. This will especially be the case when what is apparently harmless is experienced by members of the affected group as symptomatic of a wide and pervasive pattern of marginalisation and disadvantage.

Based on this he finds that the provisions do infringe on section 14 [163]. However, he finds that the "religious favouritism" must be weighed against the legitimate state purpose of wishing to diminish "the very palpable and quite terrible consequences of alcohol abuse" [171]. Because the infringement is "trivial" [168], "indirect and marginal" [174] and "slight" [177], while the dangers of excessive drinking are grave [177], the infringement is justified.

O'Regan, writing for the minority, stated that the Liquor Act infringes on religious freedom because, in the first place, it results in indirect coercion. ${ }^{50}$ In the second place, such a "public endorsement" of one religion is in itself a threat to religious freedom [123]. For O'Regan the connection between Sundays and the prohibition on trading is not tenuous at all. If the purpose had been to cover rest days, all public holidays (and presumably Saturdays) would have been included [125]. Nor does she accept that there is a legitimate purpose that can justify the infringement. In the first place the

49 S v Lawrence; S v Negal; S v Solberg 19974 SA 1176 (CC) par [156]: "Accordingly, I find it difficult to accept that state-imposed temperance on a common pause day is in itself enough to implicate section 14 simply on the grounds that that day of rest originated from and continues to coincide with the Christian sabbath."

50 S v Lawrence; S v Negal; S v Solberg 19974 SA 1176 (CC) par [120] quoting Engel v Vitale 370 US 421 (1962): "When the power, prestige and financial support of government is placed behind a particular religious belief, the indirect coercive pressure upon religious minorities to conform to the prevailing officially approved religion is plain." 
purpose cannot be to restrict consumption of alcohol, otherwise all sale of alcohol would have been prohibited [132]. In the second place, it does not prohibit the sale of alcohol on non-religious holidays [132]. As a result, the relevant section of the Liquor Act is unconstitutional.

\subsection{Sparing the rod and spoiling the child}

In the case of Christian Education South Africa $v$ Minister of Education ${ }^{51}$ Sachs $\mathrm{J}$ delivered the unanimous decision of the Court. The case dealt with an application by the appellant to declare section 10 of the Schools Act ${ }^{52}$ unconstitutional. Section 10 prohibits the administration of corporal punishment to all learners. The unconstitutionality lies in the fact that no exception is made for private schools with a Christian basis. The application is therefore for an exemption. The appellants maintain that corporal punishment is an integral part of the Christian faith and, as such, the prohibition is an infringement of religious freedom [2]. The right to administer corporal punishment is usually delegated by the parents to the teachers who act in loco parentis [5]. The respondent argued that corporal punishment is "inherently violent" and a degrading assault on personal integrity [12].

Sachs states that freedom of religion encompasses both the right to hold a belief and to practice that belief. It has both an individual and a collective dimension and "is often articulated through activities that are traditional and structured, and frequently ritualistic and ceremonial" [19]. It also includes the "right to be different" [24], especially if these beliefs are regarded by the majority as "unusual, bizarre or even threatening" [25]. The learned judge then does something that might be regarded as bizarre in itself: he does not find that section 10 does or does not infringe religious freedom, but assumes, for the sake of argument, that it does [27]. There is therefore no finding on the first stage of constitutional inquiry! Nevertheless, he proceeds to the second stage. 
Sachs does not find the proportionality analysis any easier. He points out that religious conviction is based on faith, while public and private concerns are not and must be judged on reasonableness [33]. The implication seems to be that faith and reason are once again regarded as opposites. Religion can, therefore, not be judged on reasonableness. Although it is not denied that these are seriously held beliefs of the appellants [37] the court finds that:

\begin{abstract}
Just as it is not unduly burdensome to oblige them to accommodate themselves as schools to secular norms regarding health and safety, payment of rates and taxes, planning permissions and fair labour practices, and just as they are obliged to respect national examination standards, so is it not unreasonable to expect them to make suitable adaptations to non-discriminatory laws that impact on their codes of discipline. The parents are not being obliged to make an absolute and strenuous choice between obeying a law of the land or following their conscience. They can do both simultaneously. What they are prevented from doing is to authorise teachers, acting in their name and on school premises, to fulfil what they regard as their conscientious and biblically-ordained responsibilities for the guidance of their children.
\end{abstract}

\title{
3.3 How bizarre is bizarre really?
}

The decision in Prince $v$ President of the Law Society of the Cape and others $^{53}$ once again dealt with religious freedom, but this time the cracks began to show. The applicant applied to the Law Society to have his contract for community service registered. In this application he not only disclosed two previous convictions for possession of cannabis, but also indicated his intention to continue using it for religious purposes. The Law Society took the view that his convictions disqualified him on the grounds that he is not a "fit and proper person" and refused to register to contract.

The appellant appealed against this decision on the basis that his religion (Rastafarianism) required the use of cannabis. The argument in the Constitutional Court was not that all use of cannabis should be allowed, but

53 Prince $v$ President of the Law Society of the Cape and others (CCT 36/00). Numbers in brackets in the text refers to paragraphs in the judgement. 
that the relevant legislation ${ }^{54}$ is overbroad in that it does not provide for an exemption for religious use. The court found for the respondents by a very narrow margin of 5 to 4 .

The majority decision, written by Chaskalson CJ, Ackerman J and Kriegler J, had no trouble in finding that Rastafarianism is a religion and that the legislation did indeed infringe the religious freedom of Rastafari [97]. The question of justification was, however, a different matter. The majority start off by explaining that cannabis is used for religious purposes by Rastafari and this use can be extensive [99] and is regarded by most Rastafari as central to their religion [103]. The main problem that they foresee, is the following:

The religion does not regulate the use or possession of cannabis by its members nor is there any organisation that could provide internal supervision of their acquiring, transporting, possessing or using it. Indeed, on the evidence there are too few adherents of the religion in the country and they are too thinly spread and loosely associated for truly reliable and informative answers to be possible in response to most of the questions posed in paragraph 2 of this Court's order of 12 December 2000.

The court also points out that the history of the prohibition of the use of cannabis is irrelevant [105], nor is the court's view on the desirability of the legislation relevant [109]. "The only question is whether the law is inconsistent with the Constitution" [109].

Having found that the legislation does indeed infringe upon the freedom of religion, the Court then moved on to the justification phase and found that the infringement is indeed justified [111]. The reason for this has to do with the institutional view of religion expressed earlier and goes something like this: There is substantial illicit trade in cannabis. If Rastafarianism had a stronger institutional character, it might have been possible to control the use of the drug by means of a "carefully controlled chain of permitted supply". But because this religion lacks that institutional character, there is nothing to

54 The relevant legislation is section 4(b) of the Drugs and Drug Trafficking Act 14 of 1992 and section 22A(10) of the Medicines and Related Substances Control Act 101 
distinguish the "island of legitimate acquisition and use by Rastafari for the purpose of practising their religion" from the "surrounding ocean of illicit trafficking and use" [130].

The point is therefore that the state's ability to enforce the drug legislation weighs more heavily than the Rastafari's freedom of religion in this proportionality analysis [132, 139]. The interesting thing here is how this religion is set up to fail. If you use a test for religion that is anathema to the very religion you are describing [101], then that very lack of compliance can be the basis for the failure to establish a formal control structure.

The minority judgement starts with a very thorough explanation of the use and role of cannabis in the Rastafari religion [15-20]. The upshot is to emphasise the centrality of cannabis to the Rastafari. According to Ngcobo, writing for the minority, religious freedom includes:

a) the right to entertain the beliefs that you have;

b) the right to announce those beliefs; and

c) the right to manifest those beliefs through practice, teaching and dissemination [38].

It is not in dispute that Rastafari is a religion, nor is it in dispute that the appellant is a genuine follower of that faith, or that the use of cannabis is central to that faith. [40] He also points out that religion is a matter of faith and belief and what people believe may strike others as "bizarre, illogical and irrational" [42]. But in this case, the faithful are being forced to choose between following their religion or complying with the law. Clearly, then, their freedom of religion is being infringed upon.

Nor does the minority believe that this limitation can be justified. South African society is diverse and the constitution recognises and protects this diversity. "The protection of diversity is the hallmark of a free and open society" [49]. Although the state has a clear interest in prohibiting drug abuse, at least some forms of use of cannabis by Rastafari can be regarded as 
harmless. Yet these uses are also prohibited. Similarly, because the harmful effects of cannabis are dosage related, there can be no general prohibition.

Although the need to regulate the use of the drug is recognised, the minority argued that practical difficulties should not be allowed to determine the extent of religious freedom. Briefly stated, although the state's goal is a legitimate one, the means employed to achieve the goal is not reasonable. As a result the limitation cannot be justified.

Sachs $\mathrm{J}$ points out that the real difference between the two judgements "relates to how much trouble each feels it is appropriate to expect the state to go in order to accommodate the religious convictions and practices of what is this case is a rather small and not very popular religious community [149 - my emphasis]. Sachs agrees that the Bill of Rights in this case requires the state "to walk the extra mile".

Sachs emphasises the mystical importance of cannabis to the Rastafari [152], but also that the section 36 analysis should not set up a no-win situation [155]. Interestingly, he also warns against "requirements of contemporary society exerting a hydraulic insistence on conformity to majoritarian standards" [156]..$^{55}$ Legislation should not aggravate the feeling of marginalisation experienced by such groups outside the mainstream [157]. What is more, this type of marginalisation is only possible because the Rastafari is not a strong group whose interests cannot be ignored:

The Rastafari are accordingly not an established religious group whose interests no legislature would dare ignore. The difference of treatment lay not in the nature of the activity or exemption, but in the status of the religious groups involved. One must conclude that in the area of claims freely to exercise religion, it is not familiarity, but unfamiliarity, that breeds contempt. ... One cannot imagine in South Africa today any legislative authority passing or sustaining laws which suppressed central beliefs and practices of Christianity, Islam, Hinduism and Judaism. These are well-organized 
religions, capable of mounting strong lobbies and in a position materially to affect the outcome of elections. ${ }^{56}$

To safeguard the "right to be different" Sachs agrees with the judgement of Ngcobo.

\subsection{Comment}

In the very first case dealing with religious freedom, the Constitutional Court made it clear that there is an important difference between the South African and American constitutions in that the former does not include an "establishment clause" and that American jurisprudence on this point is therefore not necessarily helpful. ${ }^{57}$ However, further analysis shows that there are interesting similarities between the South African and American case law on this point. Sullivan, commenting on American case law, shows that most cases dealing with religious freedom share a number of characteristics. ${ }^{58}$ In the first place they typically deal with forms of oppression subtler than outright persecution. In the second place, most claims dealing with religious freedom are requests for exemption and not for invalidation. In the third place, these claims for exemption come from "members of relatively politically powerless groups, towards whom the majority is likely to be selectively indifferent or worse". ${ }^{59}$ In the fourth place these cases work with a very narrow view of "coercion", based on "an overstated fear of religious anarchy". 60

It is not far-fetched to suggest that the three South African cases discussed above share the same characteristics. In none of the cases was it suggested that the legislation in question could be understood as outright persecution. ${ }^{61}$ The claim was never that the Liquor Act, for instance, was a form of religious persecution. The claim is more subtle and dealt with what one may describe as the negative right to religious freedom. Just as there is a positive right to

56 Prince $v$ President of the Law Society of the Cape and others (CCT 36/00) at [158] and [160].

57 See S v Lawrence; S v Negal; S v Solberg 19974 SA 1176 (CC) par [99] - [102].

$58 \quad$ Sullivan KM "Religion and liberal democracy" 1992 U Chicago LR 195-223.

59 Sullivan $1992 \cup$ Chicago LR 216.

60 Sullivan 1992 U Chicago LR 218-222.

61 Christian Education South Africa v Minister of Education 20004 South Africa 757 (CC) par [21]. 
practice a specific religion, there is a negative right to practice none. As Sullivan puts it: "Just as Caesar may not command one to transgress God's will, he may not command one to obey it."62 The problem with these subtle claims is that, too often, they are regarded as trifling. In some cases the court even suggests that the maxim of de minimis non curat lex should apply. ${ }^{63}$ And this indicates a kind of selective seeing and hearing on the part of the court:

Not to see the (prohibition on Sunday trading) as sending a message of exclusion to Jews, Muslims or atheists is to see the world through Christian-tinted glasses. Majority practices are myopically seen by their own practitioners as uncontroversial ...64

The fact that religious discrimination is seldom overt, results in the fact that most claims are for exemptions and not for invalidation. In South Africa that is also the case. Applicants in all cases requested an exemption to the various pieces of legislation and not that the legislation be invalidated. ${ }^{65}$ Their claim is not that the laws themselves are discriminatory, but that the facially neutral laws have an impact on religion that is incompatible with religious freedom. The problem is that the absence of direct discrimination often blinds the courts to the effect and outcome of these supposedly neutral laws.

One of the most interesting aspects of these cases is the fact that none were brought by powerful mainstream religious groups. In the Sunday trading case, no religious group was in fact involved and this factor, coupled with the court's understanding of religious freedom as a positive right, explains the decision in that case. The other two cases were brought by relatively small religious groups. In the corporal punishment case, the appellant represented 196 independent schools with a total of 14500 pupils. In the context of South African education, that is a relatively small group. Even within the main group

62 Sullivan 1992 U Chicago LR 197.

63 See S v Lawrence; S v Negal; S v Solberg 19974 SA 1176 (CC) par [139].

64 Sullivan 1992 U Chicago LR 207. Sullivan is here concerned with the specific case of the placement of a crèche or manger in public offices, but the principle can also be applied to Sunday trading.

65 Christian Education South Africa v Minister of Education 20004 South Africa 757 (CC) par [2]; S v Lawrence; S v Negal; S v Solberg 19974 SA 1176 (CC) par [91]; Prince $v$ President of the Law Society of the Cape and others (CCT 36/00) par [112]. 
of Christianity, this is a fairly small group of people. ${ }^{66}$ And, finally, the Rastafarians are, of course, the most marginal of religious groups. ${ }^{67}$

The importance of this factor cannot be overlooked. It has implications for the idea of politics as dialogue in republicanism. The problem seems to be that participation in the dialogue is premised on power - if the specific group is not powerful enough, its voice will not be heard in the conversation going on. In that sense, then, the "dialogic convention" requires power and must be conducted within the majoritarian Judeo-Christian form. Once again, the "politics of form" determines the debate. ${ }^{68}$

The politics of form is also strongly premised on the court's view of coercion. In the Sunday trading case, for instance, Chaskalson states: "It is difficult to discern any coercion or constraint imposed by section 90 of the Liquor Act ...."69 The use of force as the paradigm in deciding these cases $^{70}$ has the effect that more subtle infringements are overlooked. The modern state has far more powerful means of ensuring compliance than force or coercion. It also does not take into account that not only coercion, but also endorsement and acknowledgement of a specific religion might infringe upon religious freedom. As a result only the claims of those who have been coerced are taken into consideration and not those who are merely irritated, offended or

66 Christian Education South Africa v Minister of Education 20004 South Africa 757 (CC) par [2]. One wonders what difference is would have made had the appellant been, for instance, one of the big Christian churches whose members are in the millions.

67 The court even acknowledges this fact: Prince $v$ President of the Law Society of the Cape and others (CCT 36/00) par [157] characterises the Rastafari as a "marginalized group".

68 See Schlag P "Normativity and the politics of form" 1991 University of Pennsylvania $L R$ 801-932; Schlag $P$ "'Le hors de texte c'est moi': the politics of form and the domestication of deconstruction" 1990 Cardozo LR 1631-1674.

69 S v Lawrence; S v Negal; S v Solberg 19974 SA 1176 (CC) par [97].

70 Christian Education South Africa v Minister of Education 20004 South Africa 757 (CC) par [18]: "[F]reedom implies an absence of coercion or constraint", and par [19]: "[F]reedom of religion may be impaired by measures that coerce persons ...". See also Prince $v$ President of the Law Society of the Cape and others (CCT 36/00) par [38]: "[F]reedom of religion may be impaired by measures that force people ..." 
stigmatised. ${ }^{71}$ Coercion is easy to see. The enshrining of an unspoken and unacknowledged official religion is far more difficult to pinpoint.

\section{CONCLUSION}

At best the Constitutional Court's approach to religious freedom can be described as a typically modern one. Van der Walt describes the modern legal mind in the following way:

(It is) the tendency to search for and the willingness to find and stabilise meaning in and solutions for legal dilemmas (even in situations where meaning is contested or precarious) with reference to what we regard as "normal": established, tried and trusted tradition, convention or consensus. ${ }^{72}$

Even when the court's theoretical pronunciations seem progressive and openminded, the practical results of its decision are to affirm the normality or stability of traditional views. For example, the view of what constitutes a religion and what is protected as religious freedom is an affirmation of traditional views and ideas. But that reliance on tradition is itself a political choice "to affirm or deny, confirm or reject, include or exclude something". ${ }^{73}$ However, if one accepts the idea of the "interpretive turn"74 in law, such reliance on tradition or convention as a source of stable meaning is suspect, because it implies a reliance on the politics of convention, consensus and tradition.

What then is the view of politics that emerges from these judgements? In Michelman's terms all three decisions privilege law-rule over self-rule. In every one of the cases, the exemption sought was denied because of some over-arching state purpose. This does not mean that any or all of the decisions are necessarily wrong, but merely that they illustrate something about the approach of the court. It is an approach of deference to external

71 Sullivan 1992 U Chicago LR 204-205.

72 Van der Walt AJ 2000 Stell LR 23.

73 Van der Walt 2000 Stell LR 233.

74 The "interpretive turn" refers to the debate about the indeterminacy of meaning in law (as in other social sciences). 
authority, an acceptance of the state as arbiter of what "the good life" should be. In the words of Sullivan, it does not show much faith in faith. ${ }^{75}$

More importantly, for current purposes, is the fact that the court in no way measures up to the republican ideal. Where republicanism seeks to include those traditionally excluded (the "other"), the court's reliance on traditional ideas of what constitutes religious freedom silences those voices. At no point, for instance, is the right not to believe ever acknowledged. In fact, the decision in the Sunday trading case suggests an impatience on the part of the court with what it views as "trifling" issues. But it is only trifling if viewed from a very specific angle and that angle tends to leave the self-enclosing and selfsatisfied assumptions unchallenged. As such, the court fails to live up to the republican ideal.

But the decisions also expose a problem in republicanism, namely the close relationship between power and participation in the republican dialogue. As Michelman points out, politics depends on social and economic conditions which, in turn, depend on the legal order. However, for socially and economically powerless groups (like the Rastafari) participation in public dialogue might be a problem. Major religious groups seldom approach the court for exemptions, simply because they have enough political clout to have their needs met on the legislative level. It turns out then that power is a prerequisite for participation in the republican dialogue and that raises the old problem of the repression of minority views in classical republicanism.

If the courts are to be involved in "a kind of normative tinkering", and I have no doubt that they should, then claims based on religious freedom should receive a much stricter scrutiny when the appellants come from a small or marginalized religious group. I also have no doubt that the concept of religious freedom needs to be expanded so as to include the right not to believe. But that would require a court that is willing to abandon its benedictory role in favour of a prophetic role; a court that is willing to tinker with majority assumptions about stability and normality. 